\title{
Article \\ Stress Response of Miscanthus Plants and Soil Microbial Communities: A Case Study in Metals and Hydrocarbons Contaminated Soils
}

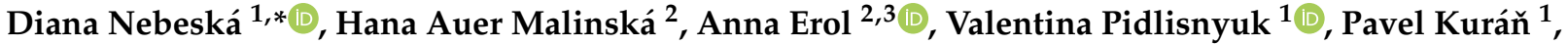 \\ Andrea Medžová ${ }^{2}$, Martin Smaha ${ }^{1}$ and Josef Trögl ${ }^{1}$ (D)
}

1 Department of Environmental Chemistry and Technology, Faculty of Environment, Jan Evangelista Purkyně University in Ústí nad Labem, 40096 Ústí nad Labem, Czech Republic; valentyna.pidlisniuk@ujep.cz (V.P.); pavel.kuran@ujep.cz (P.K.); josef.trogl@ujep.cz (J.T.); martinsmaha@seznam.cz (M.S.)

2 Department of Biology, Faculty of Science, Jan Evangelista Purkyně University in Ústí nad Labem, 40096 Ústí nad Labem, Czech Republic; hana.malinska@ujep.cz (H.A.M.); anna.erol@umb.edu.pl (A.E.); andrea.medzova@gmail.com (A.M.)

3 Clinical Research Centre, Medical University of Białystok, 15-276 Białystok, Poland

* Correspondence: diana.nebeska@ujep.cz; Tel.: +420-475-284-113

Citation: Nebeská, D.; Auer

Malinská, H.; Erol, A.; Pidlisnyuk, V.; Kuráň, P.; Medžová, A.; Smaha, M.;

Trögl, J. Stress Response of Miscanthus

Plants and Soil Microbial

Communities: A Case Study in

Metals and Hydrocarbons

Contaminated Soils. Appl. Sci. 2021,

11, 1866. https://doi.org/10.3390/ app11041866

Academic Editors: Rafael Núñez and Natalia Pozdnyakova

Received: 11 January 2021

Accepted: 16 February 2021

Published: 20 February 2021

Publisher's Note: MDPI stays neutral with regard to jurisdictional claims in published maps and institutional affiliations.

Copyright: (c) 2021 by the authors. Licensee MDPI, Basel, Switzerland. This article is an open access article distributed under the terms and conditions of the Creative Commons Attribution (CC BY) license (https:/ / creativecommons.org/licenses/by/ $4.0 /)$.
Featured Application: The potential application of results is in phytomanagement of contaminated sites (combined phytoremediation with biomass production).

Abstract: Second-generation biofuel crop miscanthus is one of the most promising plants tested for phytomanagement of contaminated sites. In this preliminary pot case study, the most used hybrid Miscanthus $x$ giganteus was cultivated in three different real contaminated soils: agricultural soil contaminated with $\mathrm{Cd}$; post-military soil slightly contaminated with $\mathrm{Zn}, \mathrm{Pb}$ and $\mathrm{Cd}$; and soil contaminated by petroleum industry with metals and hydrocarbons. The stress response of plants and soil microbial communities was monitored to receive data that are important for successful phytomanagement application. With metals only, the plant grew well, and chlorophyll fluorescence measurement proved their good vitality. Changes in leaf anatomy (leaf thickness and sclerenchyma cells area) were additionally determined in post-military soil compared to agricultural. On the contrary, in petroleum-contaminated soil, the biomass yield was too reduced and also physiological parameters were significantly decreased. The response of microbial communities also differed. In agricultural soil, no microbial stress was determined. In post-military soil, it became reduced during the experiment, and in petroleum contamination, it increased year-on-year. It could be concluded that miscanthus is suitable for cultivation in metals contaminated soils with potential for microbial communities support, but in soil contaminated by the petroleum industry, its application did not seem meaningful.

Keywords: abiotic stress; chlorophyll fluorescence; heavy metals; Miscanthus x giganteus; petroleum hydrocarbons; phytomanagement; soil microbial communities

\section{Introduction}

Contamination of soil is one of the most severe current environmental issues. A wide range of chemical compounds has been contaminating soil resources for a couple of centuries with industry development, intensification of agriculture, and other human activities. Heavy metals, petroleum hydrocarbons, pesticides and solvents were identified as the most common ones. These contaminated areas may affect ecosystems' functions, and they can cause several health problems [1]. On the other hand, with proper decontamination management, some of these sites represent non-food agronomy production opportunities. Growing energy crops in different marginal lands is a very actual topic because of limited sources of good quality agricultural soil [2]. 
One of the promising biomass production plants in contaminated sites is Miscanthus $x$ giganteus $(M x g)$ [3]. This C4 perennial grass can tolerate high concentrations of heavy metals in soil without significant uptake of metals to shoot part [4-7]. It has low nutritional content requirements in soil [8], fertilization and pesticides [9]. Additionally, it can improve soil parameters with an increase of soil carbon content [10] and soil microbial communities [11]. Together with these environmental benefits, good shoot biomass yield and biomass parameters are suitable for different processing methods [9,12-16].

The behaviour of $M x g$ grown in metals-contaminated soils has already been intensively studied in recent years $[4,5,7,17-19]$, but only several studies were carried out with Mxg growing in soils contaminated with organic pollutants. Techer et al $(2011 ; 2012 a, b)$ described Mxg tolerance in PAH contaminated soil (364 $\pm 59 \mathrm{mg} / \mathrm{kg}$ PAH with pyrene as the main compound) and production of root exudates which could be involved in the biostimulation of PAH-utilizing soil bacteria. Nurzhanova et al. [20] tested Mxg ability to grow in soil contaminated with organochlorine pesticides (DDT and $\mathrm{HCH}$ and their metabolites and isomers) with good results at the first growing season (specific values of biomass have not been reported).

According to our knowledge, there are no published data about the possibility of using $M x g$ in soils contaminated dominantly by aliphatic petroleum hydrocarbons, one of the most abundant contaminants of soils because of improper transport storage of fuels, petroleum industry activities or accidents [21,22].

External conditions, such as contamination, can play an important role in plant internal processes, resulting in change of fitness and potentially in decrease of biomass yield $[23,24]$. That could significantly decrease phytomanagement effectiveness or even disable its realization. One of the most vulnerable processes is the primary plant process, photosynthesis. It has been reported before that abiotic stress can influence the photosynthetic activity of higher plants. Photosystem II (PSII) plays significant role in the primary phase. Unfortunately, its key components, proteins D and D2 are sensitive susceptible to certain types of stress $[25,26]$. Together with the sensitivity of chlorophyll, systems of primary photosynthetic phase are perfect targets to study response of plants to abiotic stress. In this study of non-destructive method of leaf fluorescence measurement was used, taking advantage of chlorophyll $a$ fluorescence kinetics [27-31]. It was combined with the determination of leaf anatomy changes by microscopy to explore $M x g$ stress response in different contaminants.

Another focus of this study was on the state and development of soil microbial communities and their stress response in contaminated soils during the experiment. Soil microorganisms play a key role in soil health and the hydrocarbons degradation process. Therefore, the potential positive effect of $M x g$ on soil microbial communities could be significant for the overall improvement of soil quality and for the following research in organic compounds phytoremediation. This information could be beneficial because rhizodegradation combining the function of microorganisms and plants is considered as one of the most promising low-cost in situ methods for organic compounds removal from the environment [32].

Based on previous information, it was hypothesized that $M x g$ will be able to grow successfully in all types of selected soils contaminated by metals and hydrocarbons and the soil microbial communities' stress will be reduced during $M x g$ cultivation. To investigate these issues, we prepared a preliminary pot case study with real soils contaminated by various past activities, including the petroleum industry, to receive first data about $\mathrm{Mxg}$ behaviour in such conditions. Additionally, the soils contaminated by agronomy and military activities were selected. Real contaminated soils were used instead of artificially contaminated soils to simulate the real application on lab scale as close as possible. 


\section{Materials and Methods}

\subsection{Experiment Design}

Two years pot experiment was established with second-generation energy crop $M x g$ (rhizomes from three-year-old plants), produced by the Institute of Sugar Beets and Bioenergy crops, Ukraine. Two rhizomes were planted in each pot and grown from May 2016 to November 2017 under greenhouse conditions. A total of $1 \mathrm{~kg}$ of ceramzite as drainage and $1 \mathrm{~kg}$ of sand were put in every pot together with $10 \mathrm{~kg}$ of soil. The size of the pot was $35 \mathrm{~cm}$ upper diameter and $19.5 \mathrm{~cm}$ lower diameter (approximately $17 \mathrm{~L}$ volume).

Three soil variants were prepared in duplicates: post-military soil (MIL) from former military airport Hradčany, agricultural soil (AGR) from nearby farms and petroleumcontaminated soil (OIL). Characterization of all soils is provided in Table 1. Soils were sieved through $1 \mathrm{~cm}$ mash and homogenized before the experiment establishment.

Table 1. Characterization of soils used in the experiment (sample of homogenized soil prepared before planting; ${ }^{\mathrm{a}} \mathrm{n}=1$,

${ }^{b}$ mean $\left.\pm S D, n=4\right)$, the same letters behind values mark comparable results $(p<0.05)$.

\begin{tabular}{|c|c|c|c|c|}
\hline Parameter & AGR & MIL & OIL & Preventive Value * \\
\hline $\mathrm{pH}(\mathrm{KCl})^{\mathrm{a}}$ & 6.27 & 6.61 & 7.30 & - \\
\hline Available P [mg/kg dw] ${ }^{a}$ & 249 & 40 & 28 & - \\
\hline Available $\mathrm{K}[\mathrm{mg} / \mathrm{kg} \mathrm{dw}]^{\mathrm{a}}$ & 83 & 59 & 764 & - \\
\hline Available $\mathrm{Ca}[\mathrm{mg} / \mathrm{kg} \mathrm{dw}]^{\mathrm{a}}$ & 833 & 671 & 4409 & - \\
\hline Available $\mathrm{Mg}[\mathrm{mg} / \mathrm{kg} \mathrm{dw}]^{\mathrm{a}}$ & 79 & 86 & 205 & - \\
\hline TOC $[\% \mathrm{dw}]^{\mathrm{b}}$ & $1.14 \pm 0.05 \mathrm{a}$ & $1.24 \pm 0.10 \mathrm{a}$ & $4.46 \pm 0.32 b$ & - \\
\hline $\mathrm{N}_{\text {tot }}[\% \mathrm{dw}]^{\mathrm{a}}$ & 0.66 & 0.57 & 0.68 & - \\
\hline $\mathrm{S}[\% \mathrm{dw}]^{\mathrm{a}}$ & 0.09 & 0.14 & 0.22 & - \\
\hline \multicolumn{5}{|l|}{ Contamination $[\mathrm{mg} / \mathrm{kg} \mathrm{dw}]$} \\
\hline $\mathrm{C} 10-\mathrm{C} 40^{\mathrm{b}}$ & $<100 \mathrm{a}$ & $<100$ a & $8642 \pm 351 b$ & 100 \\
\hline $\mathrm{Cd}$ (aqua regia) ${ }^{\mathrm{a}}$ & 1.73 & 0.91 & 2.07 & 0.5 \\
\hline $\mathrm{Pb}$ (aqua regia) ${ }^{\mathrm{a}}$ & 15.23 & 73.22 & 86.13 & 60 \\
\hline Zn (aqua regia) a & 38.83 & 308.48 & 312.01 & 120 \\
\hline $\mathrm{Cd}\left(\mathrm{CaCl}_{2}\right)^{\mathrm{a}}$ & 0.05 & $<0.01$ & 0.01 & - \\
\hline $\mathrm{Pb}\left(\mathrm{CaCl}_{2}\right)^{\mathrm{a}}$ & 0.01 & $<0.01$ & $<0.01$ & - \\
\hline $\mathrm{Zn}\left(\mathrm{CaCl}_{2}\right)^{\mathrm{a}}$ & 4.21 & 5.13 & 4.35 & - \\
\hline
\end{tabular}

* preventive value declared in the Czech legislation; if the value is exceeded, precautions should be taken into consideration, and further inputs of the element/compound to the soil reduced [33]. TOC = total organic carbon; $\mathrm{C} 10-\mathrm{C} 40=$ aliphatic hydrocarbons with the carbon number range between $10-40$.

AGR soil was preliminary intended to serve as a control (i.e., rich soil from locality near the MIL soil which should presumably not limit the plants growth), nevertheless, the laboratory analyses revealed slight contamination by cadmium (Table 1) in levels that were not detectable during in situ screening with handheld XRF. Except for increased Cd (likely originating from the use of inorganic phosphate fertilizers, see Section 3.2), other soil parameters were appropriate for the presumed profitable growth of Mxg. Therefore, it was decided to keep this soil mainly for comparison, not to call it to control.

MIL soil was collected directly from the Hradčany airport near one of the plane hangars from the depth $0-30 \mathrm{~cm}$.

OIL soil was prepared with the intention to simulate the historical pollution of Hradčany airport with petroleum compounds. The central portion of contamination in the airport site was already removed during remediation, and residual contamination is located in deeper layers (approximately $2-4$ meters, although with high variability) $[34,35]$. Thus, it was decided to prepare OIL soil as a mixture of MIL soil and petroleum industry sludge soil (ratio 3:1; m/m) to achieve real but defined petroleum contamination. The sludge soil was previously characterized by Kakosová et al. [36] and used in previous studies [36,37]. 
During vegetation season pots were watered 2-3 times per week with rain water to prevent the substrate from drying out completely to avoid drought stress. Between the first and second growing season (i.e., after biomass collection and before the first new leaves appearance) the watering period was reduced to 2 times per month. Pot bowls were placed under the pots to ensure that all water will be absorbed by the substrate. No fertilizers were applied.

Biomass was collected at the end of vegetation season after the total senescence of all plants. Leaves and stems were air-dried and weighed separately. Soil samples were taken before starting the experiment from prepared homogenized soil (approximately $200 \mathrm{~g}$ of each soil). The second and third sampling was done at the same time as biomass collection. Two individual samples were taken across each pot profile with soil tube (only soil layer without ceramzite and sand drainage at the bottom) to eliminate soil heterogeneity. Samples were then homogenized, divided to smaller portions, adjusted and stored according to analytical methods requirements (details provided in following sections).

\subsection{Agrochemical Soil Analysis}

Agrochemical characterization of soil was realized in Crop Research Institute, Czech Republic following valid methodology compatible with ISO and CEN standards [38,39]. One sample of homogenized soil from each variant, air-dried and sieved through $2 \mathrm{~mm}$, was used for the determination of the following parameters: $\mathrm{pH}$ in the suspension of soil and water, available nutrients $\mathrm{P}, \mathrm{K}, \mathrm{Mg}$, and $\mathrm{Ca}$ in Mehlich 3 extract analysed by ICP-OES (Integra XL, GBC Scientific Equipment, Australia), total N and S determined using elemental analysis (Vario MAX CNS/CN, Elementar, Germany). Total organic carbon (TOC) was determined with a TOC analyser for solid and liquid samples (Primacs ${ }^{\text {SLC }}$, Skalar, Netherlands) in J. E. Purkyně University laboratory.

\subsection{Heavy Metals Analysis}

For heavy metals analysis, $20 \mathrm{~g}$ of soil sample was air-dried at $25^{\circ} \mathrm{C}$. Small stones, plant particles and other inclusions were removed, and the sample was sieved through $0.25 \mathrm{~mm}$. Bigger particles were ground if necessary. Pseudototal extraction was done with aqua regia by hot plate wet digestion: $21 \mathrm{~mL} \mathrm{HCl}$ and $7 \mathrm{~mL} \mathrm{HNO}_{3}$ was added to $3 \mathrm{~g}$ of soil, left for 12 hours and later boiled for 2 hours. The concentration of heavy metals in the filtered extract was determined by ICP-OES (Optima 8000, Perkin Elmer, Waltham, MA, USA). Results were compared with legislative preventive values [33], and $\mathrm{Cd}, \mathrm{Pb}$ and $\mathrm{Zn}$ were chosen for further investigation as elements with potentially risk concentration.

For determination of bioavailable fraction $3 \mathrm{~g}$ of soil sample were mixed with $30 \mathrm{~mL}$ of $0.01 \mathrm{M} \mathrm{CaCl}_{2}$ and shaken with rotary shaker for 2 hours at $10 \mathrm{rpm}$. The concentration of $\mathrm{CaCl}_{2}$ extractable metals was analysed with ICP-MS (Agilent 7900, Agilent Technologies, Santa Clara, CA, USA).

\subsection{Aliphatic Petroleum Hydrocarbons Analysis}

According to Kakosová et al. [35], who used the petroleum sludge soil from the same source, petroleum contamination was determined as C10-C40 aliphatic hydrocarbons. Soil samples were frozen at $-40^{\circ} \mathrm{C}$ right after sampling, and stones and plant roots were removed manually before analysis. ČN EN 14039 [40] method optimized for soil and sludge was used as described by Kuráň et al. [41] previously with a slight modification. Briefly, $6 \mathrm{~g}$ of soil sample was extracted by acetone and hexane with decane and tetracontane standards. The hexane extract was then purified using activated florisil. The sample was concentrated to $20-50 \mathrm{~mL}$, and the total concentration of C10-C40 was determined using GC-FID (MASTER GC, Dani Instruments, Italy). Standard BAM-K010 (mineral oil standard mixture type $\mathrm{A}$ and $\mathrm{B}$ purchased from Merck $\mathrm{KGaA}$ ) was used for calibration preparation. 


\subsection{Chlorophyll Fluorescence}

Non-destructive leaf fluorescence measurement was used to assess plant fitness [30,42] in the second year of vegetation. The third youngest fully developed leaf from the highest shoot of each plant ( 2 measures per pot) was dark adapted and measured by Handy PEA (Hansatech Instruments, United Kingdom) using measuring protocol with a weak actinic light beam $\left(50 \mu \mathrm{mol} / \mathrm{m}^{2} / \mathrm{s}\right)$ followed by saturation pulse with an intensity of $3500 \mu \mathrm{mol} / \mathrm{m}^{2} / \mathrm{s}$. The fluorescence signal was measured using a $650 \mathrm{~nm}$ detector. All plants were measured three times (April, May, September). During the summer months (JuneAugust), the temperature in the greenhouse increased unexpectedly. So, it was decided to exclude measurement of fluorescence from these months because stress measured during hot days could contribute to stress caused by soil parameters and influence the results.

Chlorophyll $a$ fluorescence intensity versus time was plotted as OKJIP transient with typical curve starting at $50 \mu \mathrm{s}\left(\mathrm{F}_{0}\right)$ and fluorescence rise in $2 \mathrm{~ms}\left(\mathrm{~F}_{\mathrm{J}}\right), 30 \mathrm{~ms}\left(\mathrm{~F}_{\mathrm{I}}\right)$ and time of maximal fluorescence $\left(\mathrm{F}_{\mathrm{P}}, \mathrm{Fm}\right)$. Another step was measured in time $300 \mu \mathrm{s}\left(\mathrm{F}_{\mathrm{K}}\right)$. These fluorescence intensity values were used for the calculation of four physiological indexes that can be used for different abiotic stress indication in plants including the $M x g[43,44]$. The four indexes are the maximum quantum yield of primary photochemistry ( $\mathrm{Fv} / \mathrm{Fm})$, the trapping at time zero per cross-section of the leaf tissue at $\mathrm{F}_{0}\left(\mathrm{TR}_{0} / \mathrm{CS}_{0}\right)$, the absorption per cross-section of the leaf tissue at Fm (ABS/CSm), and the electron transport at time

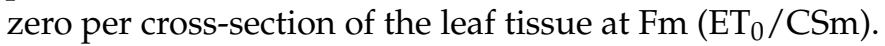

Indexes calculation was adapted from Hansatech Handy PEA manual:

$\mathrm{Fv} / \mathrm{Fm}=\left(\mathrm{Fm}-\mathrm{F}_{0}\right) / \mathrm{Fm}$

$\mathrm{TR}_{0} / \mathrm{CS}=\left(\mathrm{TR}_{0} / \mathrm{ABS}\right)(\mathrm{ABS} / \mathrm{CS})$

$\mathrm{ABS} / \mathrm{CS}=\left(\mathrm{TR}_{0} / \mathrm{ABS}\right) /(\mathrm{ABS} / \mathrm{CS})$

$\mathrm{ET}_{0} / \mathrm{CS}=\left(\mathrm{M}_{0} / \mathrm{V}_{\mathrm{J}}\right)\left(1-\mathrm{V}_{\mathrm{J}}\right)$

$\mathrm{M}_{0}=\left(\mathrm{F}_{\mathrm{K}}-\mathrm{F}_{0}\right) /\left(\mathrm{Fm}-\mathrm{F}_{0}\right)$

$\mathrm{V}_{\mathrm{J}}=\left(\mathrm{F}_{\mathrm{J}} / \mathrm{F}_{0}\right) /\left(\mathrm{Fm}-\mathrm{F}_{0}\right)$

\subsection{Microscopy}

Leaf sections ( $12 \mu \mathrm{m}$ thick) from the third fully developed leaf were prepared by mounting in tissue freezing medium, cut on a cryostat (CM1100, Leica, Germany). Sections were mounted in water. The autofluorescence was recorded at excitation of 330-385 $\mathrm{nm}$ with barrier filter $420 \mathrm{~nm}$ using NIB-100F (Novel, China) fluorescence microscope using camera Eurekam 3.0 PLUS (BEL, Italy). Images were processed for brightness and contrast only using Image J software. The same developmental stages were compared in leaf shape, the thickness of the leaf blade, and the size of sclerenchyma cells using BEL Capture 3.2 software.

\subsection{Soil Microbial Communities}

Characterization of state of soil microbial communities at the start and at the end of experiment was described by selected enzyme activities, basal soil respiration and phospholipid fatty acids (PLFA). Soil samples were divided, and part of the sample was stored in a refrigerator at $4{ }^{\circ} \mathrm{C}$ for up to 14 days for microbial activity determination and the rest was frozen at $-40{ }^{\circ} \mathrm{C}$ for PLFA analysis.

Hydrolases (phosphatases, arylsulphatases, proteases, glucosidases) and dehydrogenases activities were determined spectrophotometrically after the incubation of the soil sample with artificial substrates leading to coloured product, p-nitrophenol in the case of hydrolases [45] and triphenylformazan for dehydrogenases [46]. Basal soil respiration was determined as $\mathrm{CO}_{2}$ captured in $\mathrm{NaOH}$ after incubation with the soil sample by reversed titration [46].

Determination of indicator PLFA and calculation on cy/pre indicator [47] was selected to quantify soil microorganisms stress response during the experiment.

PLFA were determined using a simple extraction method according to Baldrian et al. [48] with a different GC column and modified temperature program. Briefly, the method consisted of extraction of total lipids from $10 \mathrm{~g}$ of a soil sample by a single-phase mixture of 
chloroform, methanol, and phosphate buffer $(10: 20: 8 \mathrm{v} / \mathrm{v} / \mathrm{v})$, isolation of phospholipids by solid-phase extraction on silica columns, derivatization by mild alkaline methanolysis and determination of produced fatty acid methyl esters by gas chromatography (GC 3800, Varian, USA) with polar Agilent J\&W HP-88 column $(60 \mathrm{~m} \times 0.25 \mathrm{~mm} \times 0.2 \mu \mathrm{m})$, helium as carrier gas $(0.6 \mathrm{~mL} / \mathrm{min})$, splitless injection $\left(3 \mu \mathrm{l}, 0.2 \mathrm{~min}, 240^{\circ} \mathrm{C}\right)$, temperature program $\left(100{ }^{\circ} \mathrm{C}\right.$ for $2 \mathrm{~min} ; 4^{\circ} \mathrm{C} / \mathrm{min}$ to $240{ }^{\circ} \mathrm{C}, 8 \mathrm{~min}$ ) and using a mass spectrometry ion trap detector (MS 4000, Varian, Cary, NC, USA), transfer line at $250{ }^{\circ} \mathrm{C}$, ion trap temperature at $180{ }^{\circ} \mathrm{C}$, the manifold temperature at $40{ }^{\circ} \mathrm{C}$, and monitored mass range from 33 to 450 amu. Total PLFA ( PLFA $_{\text {tot }}$ ) serving as an indicator of living microbial biomass were determined as a sum of all peaks in a range of qualitative standard Bacterial Acid Methyl Ester (BAME) Mix purchased from Merck KGaA (between 11:0 and 2OH-16:0). Cy/pre stress indicator (cy/pre PLFA) was calculated as ratio of cyclopropyl fatty acids and their precursors (cy17:0+cy19:0)/(16:1 $\omega 7+18: 1 \omega 7)$.

\subsection{Statistics}

Unpaired Kruskal-Wallis test was used to analyse Fv $/ \mathrm{Fm}, \mathrm{TR}_{0} / \mathrm{CS}_{0}, \mathrm{ABS} / \mathrm{CSm}$ and $\mathrm{ET}_{0} / \mathrm{CSm}$ chlorophyll fluorescence parameters, and microbial indicator $c y /$ pre PLFA. For microbial indicator $c y /$ pre PLFA, the number of 36 independent observations has been grouped in 9 groups, dependent on soil (AGR, MIL, OIL) and Season (Start, Season 1, Season 2). As the normal distribution could not be assumed, the non-parametrical multiple comparison method was chosen because of limited sample size. The significance level was set for $\alpha=0.05$. The data were analysed using R version 3.6.1 [49]-"Action of the Toes". For the $95 \%$ significant Kruskal-Wallis test results, a post-hoc test-pairwise comparisons using the Wilcoxon rank-sum test was conducted.

Results in Table 1 (TOC and C10-C40), C10-C40 concentrations development during experiment and microbial activities with microbial biomass were tested using unpaired Kruskal-Wallis test, and for 95\% significant results Mann-Whitney U Test was used to compare individual groups. Data for leave thickness were compared by T-test for independent samples because 24 individual observations were available for each group. Both Mann-Whitney U Test and T-test were conducted for size of sclerenchyma areas. Those tests were done in software TIBCO Statistica 13.3.

\section{Results}

\subsection{Soil Agrochemical Parameters}

Soil pH ranged from slightly acidic (AGR) and neutral (MIL) to slightly alkaline (OIL). Accessibility of nutrients ( $\mathrm{P}, \mathrm{K}, \mathrm{Mg}, \mathrm{Ca}$ ) also varied between soils (Table 1 ). The concentration of available $\mathrm{P}$ in AGR soil was very high, and on the contrary, it was low in MIL and OIL soil compared to Czech legislative agronomic standards [50]. While in AGR and MIL soil, the concentration of available $\mathrm{Mg}$ was convenient, and the concentration of $\mathrm{K}$ was even low. In OIL soil, they were both very high. Available Ca concentration was by far the highest in OIL, 5-6 times that of AGR and MIL. Level of total N was high in all soils. Content of TOC was significantly higher in OIL soil compared to AGR and MIL. Nevertheless, considering C10-C40 values it may be presumed that it was caused most likely by petroleum contaminants than a higher portion of organic matter.

\subsection{Contamination}

As illustrated in Table 1, only concentration of Cd exceeded preventive value in all soils from selected potentially toxic heavy metals, including AGR. Higher Cd concentration, both pseudo total and bioavailable, in AGR soil compared to MIL soil from the same region was most likely caused by the application of phosphorous fertilizers, which may serve as a Cd source [51]. This assumption was supported by an elevated concentration of $\mathrm{P}$ in AGR soil. While the level of $\mathrm{Zn}$ in MIL and OIL was similar, $\mathrm{Pb}$ and $\mathrm{Cd}$ increased with petroleum-contaminated soil. C10-C40 aliphatic hydrocarbons were determined only in OIL soil. This concentration exceeded preventive value by two orders. It reflected 
the contamination level by fuel leaks in some areas of Hradčany airport locality during the remediation process [34]. During two years concentration of C10-C40 was gradually reduced by $40 \%$ (Table 2 ).

Table 2. Concentration of aliphatic hydrocarbons (C10-C40) in soil during experiment (mean \pm SD, $\mathrm{n}=4)$, the same letters behind values mark comparable results $(p<0.05)$.

\begin{tabular}{cccc}
\hline \multirow{2}{*}{ Variant } & \multicolumn{3}{c}{ C10-C40 [mg/kg dw] } \\
\cline { 2 - 4 } & Start & 1st Season & 2nd Season \\
\hline AGR & $<100 \mathrm{a}$ & $<100 \mathrm{a}$ & $<100 \mathrm{a}$ \\
MIL & $<100 \mathrm{a}$ & $<100 \mathrm{a}$ & $<100 \mathrm{a}$ \\
OIL & $8642 \pm 351 \mathrm{~b}$ & $6854 \pm 782 \mathrm{c}$ & $5155 \pm 701 \mathrm{~d}$ \\
\hline
\end{tabular}

\subsection{Biomass}

Dry biomass yield was the highest in AGR soil (214 $\mathrm{g}$ from 4 rhizomes in the second year). However, for MIL, the biomass amount $(181 \mathrm{~g})$ was still quite satisfying and applicable for further processing. On the other hand, in OIL soil, only up to $6 \mathrm{~g}$ of dry biomass was produced from four rhizomes (Figure 1). The ratio of stems was higher in AGR (53\%) and MIL (59\%) than leaves in the first year of growth, but the second year and OIL soil, the leaves made up most of the biomass weight.

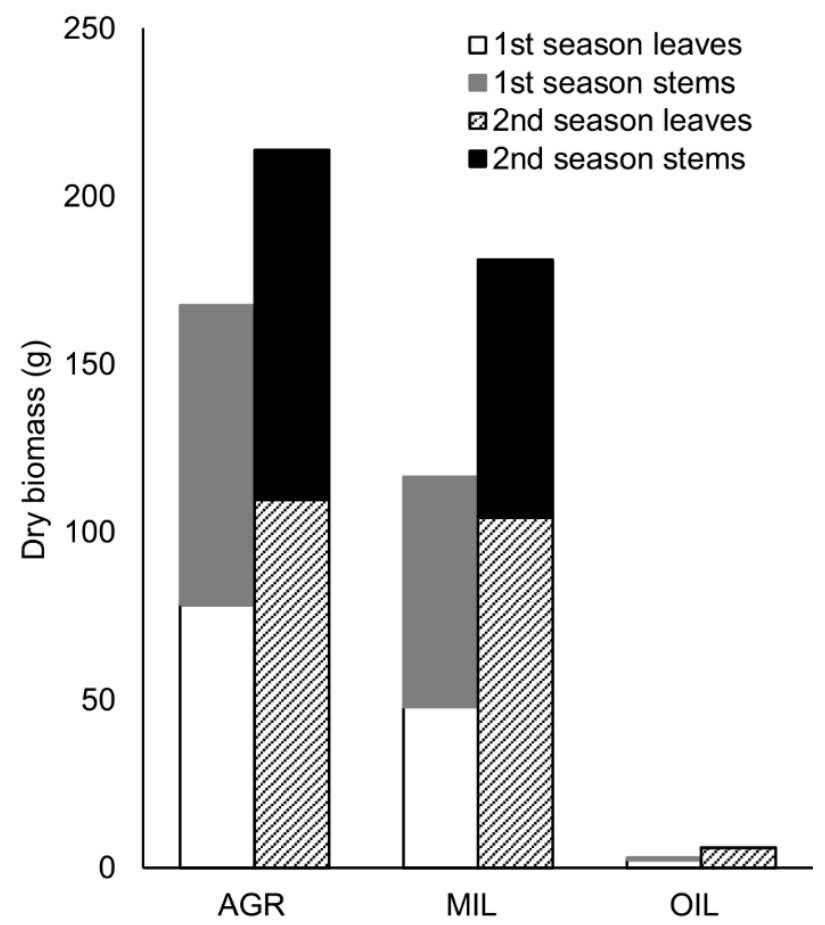

Figure 1. Production of dry biomass per variant (sum of 2 pots, 4 rhizomes)

\subsection{Chlorophyll Fluorescence}

OJIP curves (Figure 2) were reconstructed from means of all measurements to show the difference in chlorophyll $a$ fluorescence induction curve in three studied groups. Plants grown in post-military soil (MIL) showed similar transient as the plants grown in agricultural soil (AGR), although values were slightly lower. Plants incubated in oil-polluted soil (OIL) exhibit much lower fluorescence signals than the other two groups. 


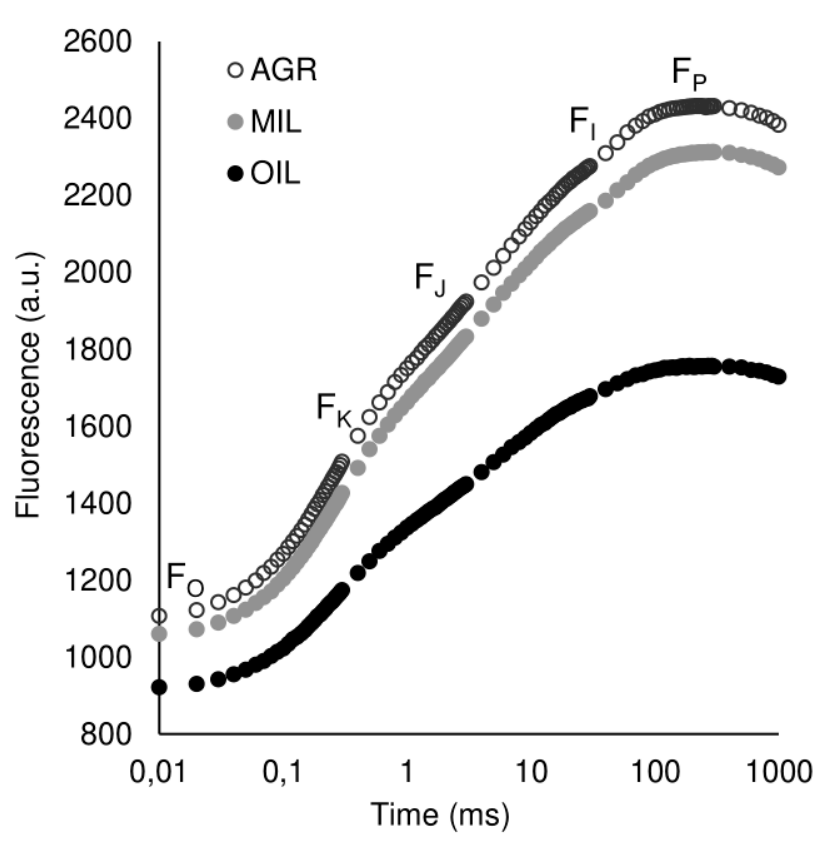

Figure 2. OKJIP polyphasic fluorescence rise of plants grown in different soils plotted on a logarithmic scale (mean value, $\mathrm{n}=12$ )

Based on fluorescence measurements, common parameters were calculated to characterize plant fitness via the use of light (Figure 3). The most common parameter Fv / Fm (Figure 3a) showed a lower median value of OIL. However, this difference was not statistically significant. Another three selected indexes: $\mathrm{TR}_{0} / \mathrm{CS}_{0}$ (Figure 3b), $\mathrm{ET}_{0} / \mathrm{CSm}$ (Figure $3 \mathrm{c}$ ) and ABS/CSm (Figure 3d), which are not so often used in literature, confirmed lower values of OIL. For these indexes, the difference was even statistically significant. Additionally, OIL results exhibited much higher variability. AGR and MIL parameters were comparable.

a

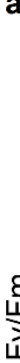

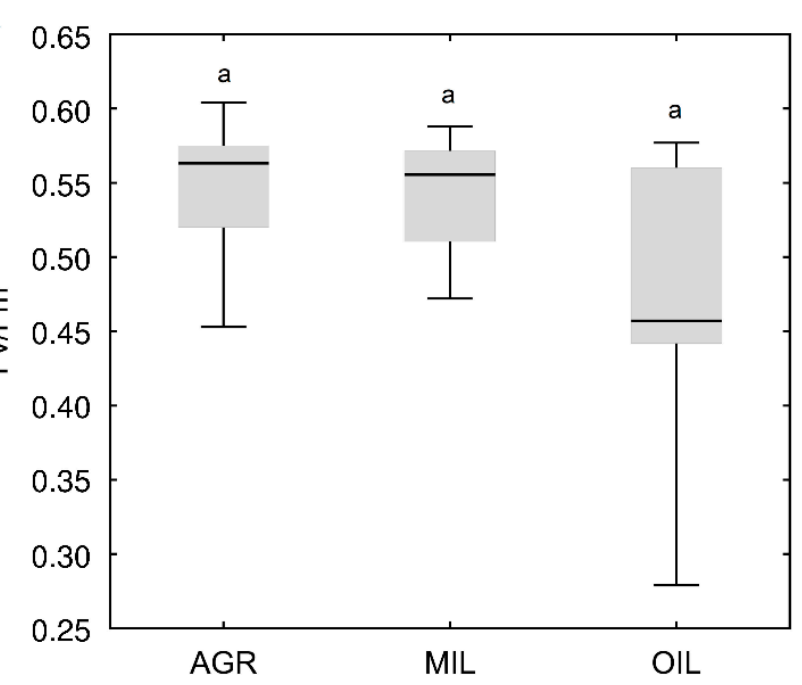

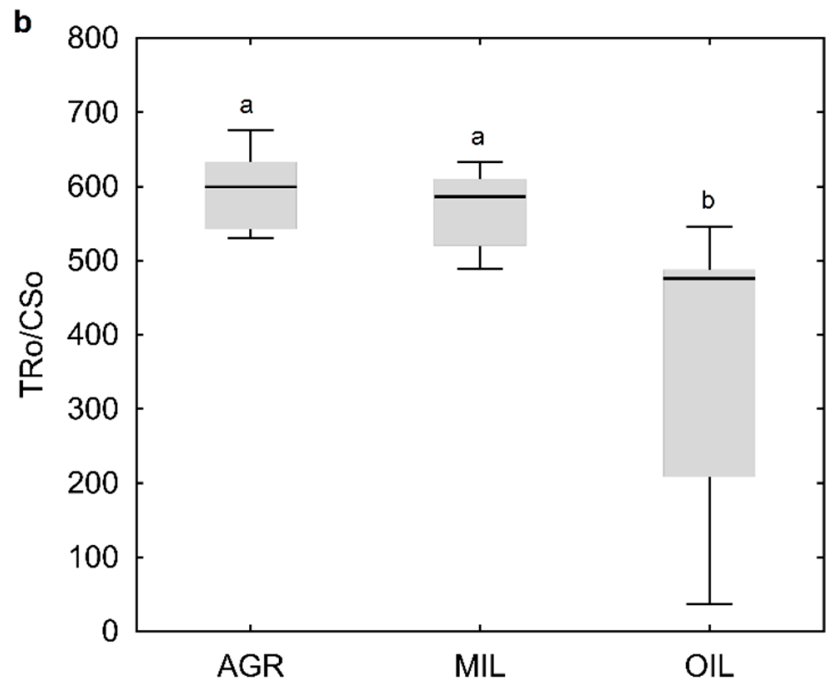

Figure 3. Cont. 
C

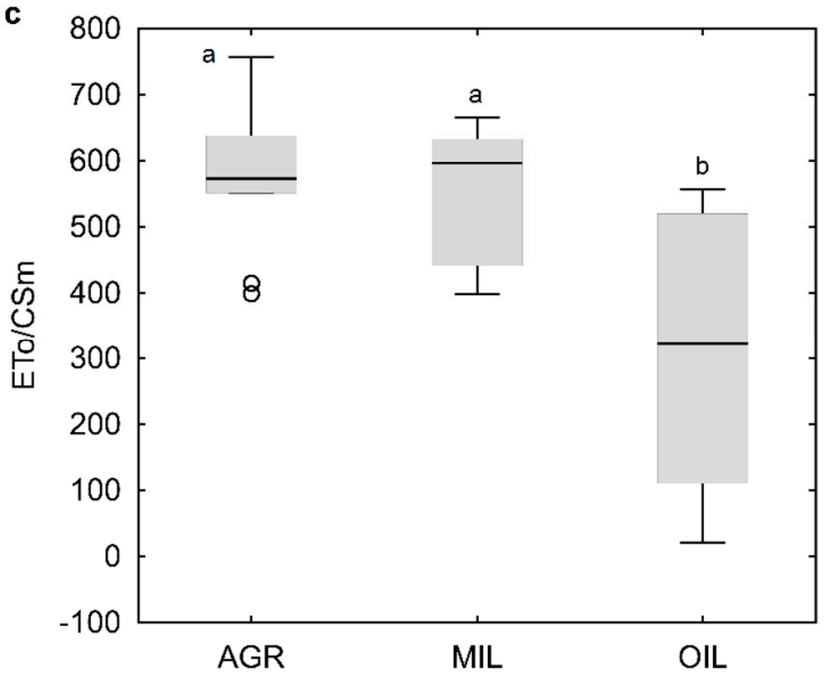

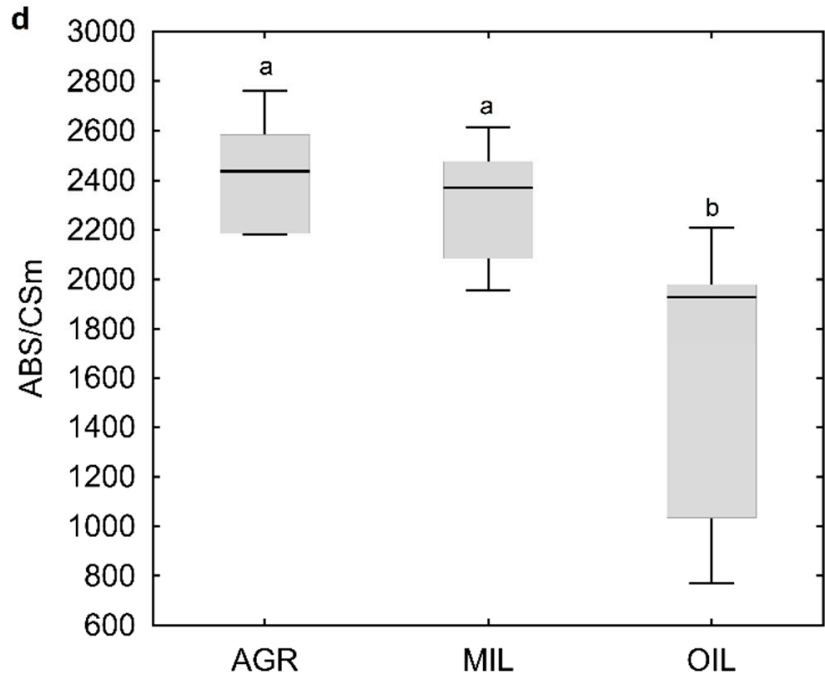

Figure 3. Physiological indicators Fv/Fm (a), $\mathrm{TR}_{0} / \mathrm{CS}_{0}(\mathbf{b}), \mathrm{ET}_{0} / \mathrm{CSm}(\mathbf{c})$ and ABS/CSm (d) (line: median, box: first-third quartile, whiskers: non-outlier range, circle: outlier); the same letters above boxplots mark comparable groups according to Wilcoxon rank sum test $(p<0.05)$

\subsection{Microscopy}

Leaf sections of the area $1 \mathrm{~cm}$ far from leaf tip (Figure 4) seemed to be similar in a plant grown in agricultural (AGR) and in post-military soil (MIL), although the difference in size/developmental stage of vascular bundles could be found. In the AGR variant, younger bundles seemed to be more developed than the appropriate bundle in the MIL variant. In addition, the size of sclerenchyma areas that were slightly different within both groups (Figure 5) was mainly around the leaf's main vascular bundle. Certain differences were observed on the tip of the leaf blade, but these differences were also connected to which side of the leaf was measured, in other words, how the leaf was packed (parametric T-test proved difference of central sclerenchymatic area 4 and side area 2a but it was not confirmed by nonparametric variant of the test which was used because of the low number of replicates). Figure 6 shows that the AGR leaf was slightly thicker than the MIL leaf.

In the $5 \mathrm{~cm}$ section (Figure 7), all differences between these two variants became obvious. AGR plants possessed thick sclerenchyma layers along with big vascular bundles. Those were mostly located at the edge of the leaf blade. Moreover, the entire leaf of AGR plants was also covered by a thick cuticle.
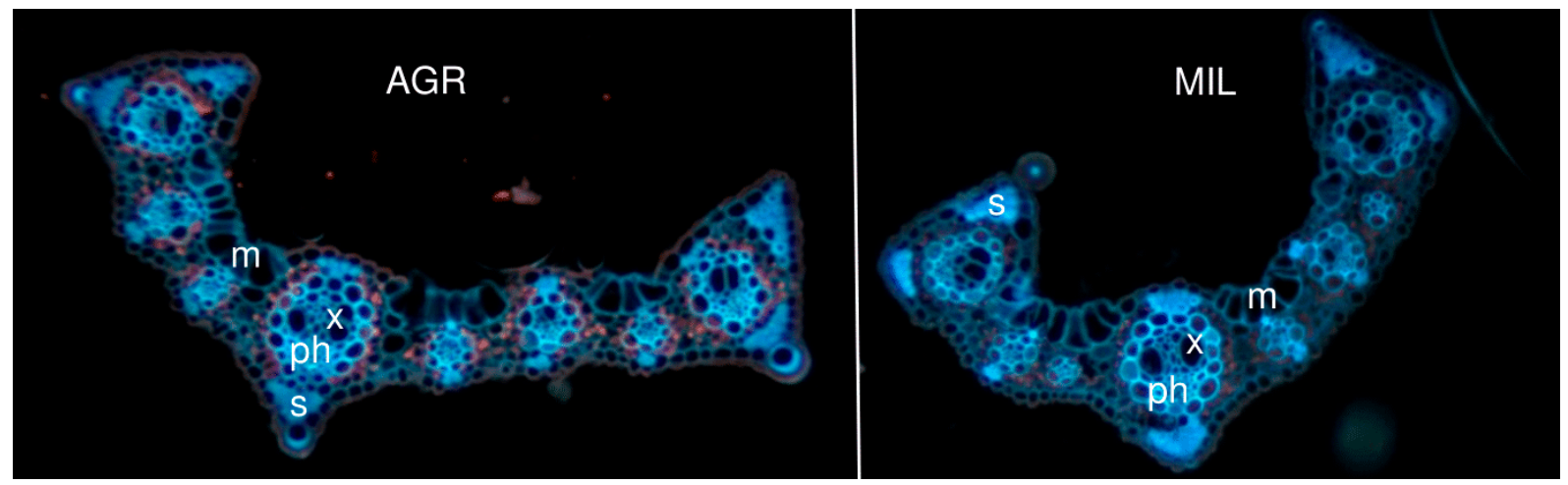

Figure 4. Leaf section (1 cm from tip), m: motor cell, x: xylem, ph: phloem, s: sclerenchyma area. 


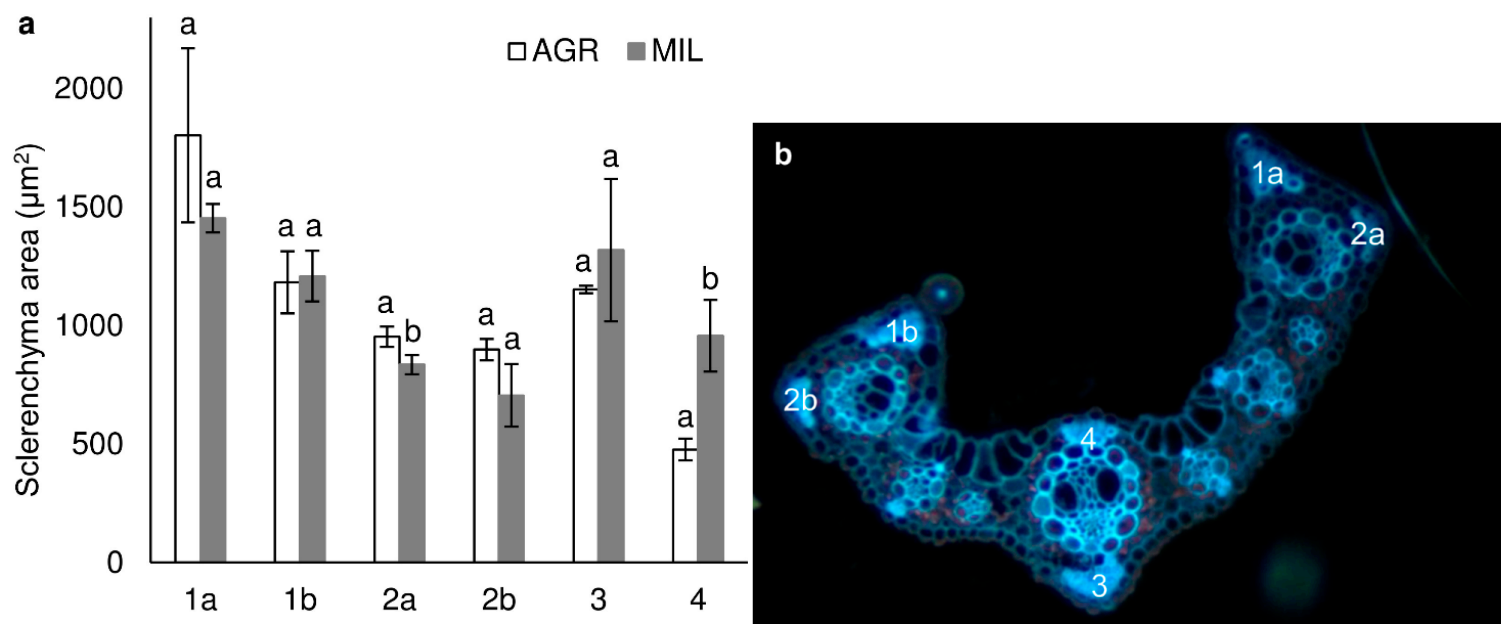

Figure 5. Size of 4 sclerenchyma areas in $1 \mathrm{~cm}$ leaf section (a) (mean $\pm S D, n=3)$ and sclerenchyma area position (b), the same letters above bars mark comparable groups according to T-test $(p<0.05)$ - only results for AGR and MIL for the same sclerenchyma area are compared mutually.

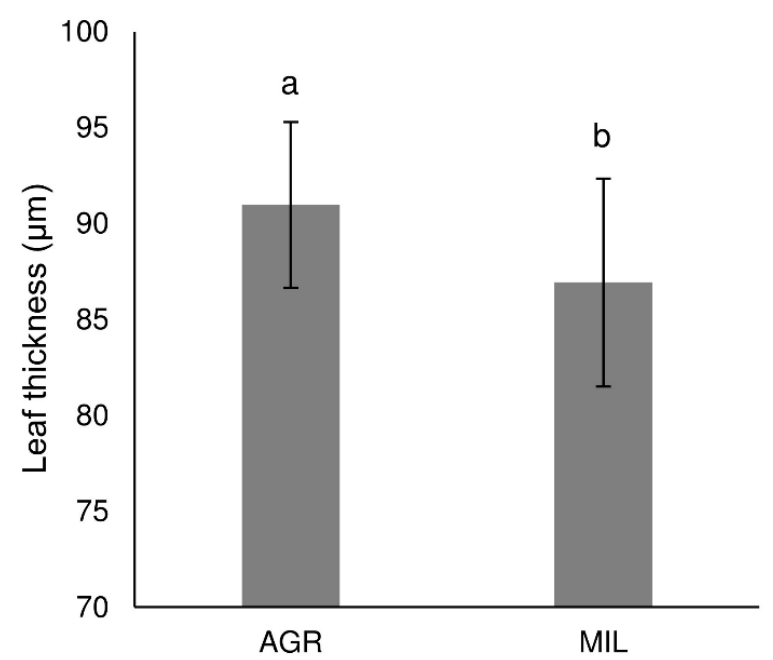

Figure 6. Leaf thickness in section taken $1 \mathrm{~cm}$ from leaf tip (mean $\pm S D, n=24$ ), the same letters above bars mark comparable groups according to T-test $(p<0.05)$

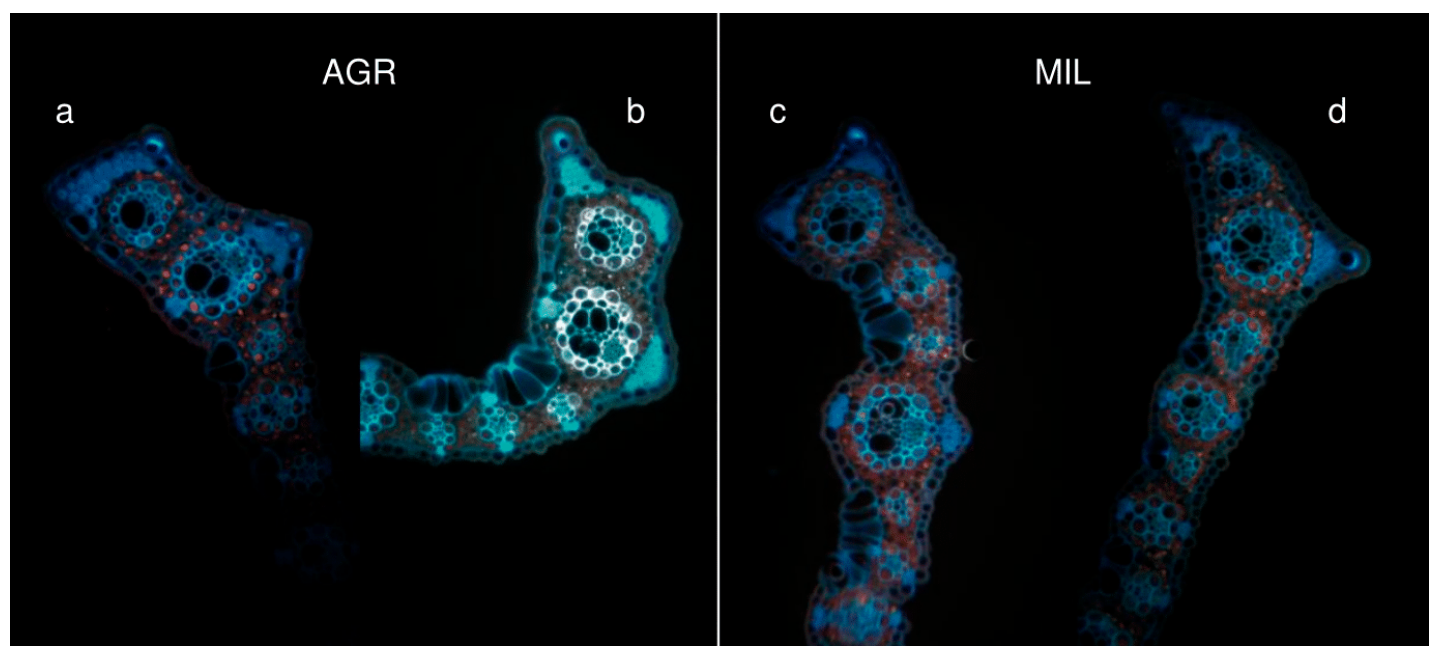

Figure 7. Differences of leaf shapes (5 cm from tip), inner part of the leaf $(\mathrm{a}, \mathrm{c})$, outer part of curled leaf $(\mathrm{b}, \mathrm{d})$ 


\subsection{Soil Microbial Communities}

Quantification of living microbial biomass $\left(\mathrm{PLFA}_{\text {tot }}\right)$, respiration and dehydrogenase activity (Table 3) showed the highest values in OIL soil, which is the most contaminated one, while AGR and MIL values were significantly lower. On the contrary, hydrolytic enzymes, produced by organisms to increase available nutrients, had the highest activities in MIL soil with the exception of proteases which were comparable with OIL value.

While microbial biomass and respiration did not change significantly during experiment, partial changes in enzymatic activity values were observed.

Table 3. Microbial and enzyme activities and microbial biomass (PLFA $\left.A_{\text {tot }}\right)\left(\right.$ mean $\left.\pm S D,{ }^{a} n=8,{ }^{b} n=4\right)$, the same letters behind values mark comparable results $(p<0.05)$.

\begin{tabular}{|c|c|c|c|c|c|c|}
\hline \multirow{2}{*}{ Parameter } & \multicolumn{2}{|c|}{ AGR } & \multicolumn{2}{|c|}{ MIL } & \multicolumn{2}{|c|}{ OIL } \\
\hline & Start & End & Start & End & Start & End \\
\hline Respiration $[\mathrm{mU} / \mathrm{g} \mathrm{dw}]^{\mathrm{a}}$ & $3.63 \pm 0.55 a$ & $2.78 \pm 1.5 \mathrm{a}$ & $3.17 \pm 0.55 \mathrm{a}$ & $3.42 \pm 0.98 \mathrm{a}$ & $6.35 \pm 1.30 \mathrm{~b}$ & $4.8 \pm 0.94 \mathrm{ab}$ \\
\hline Dehydrogenase $[\mu \mathrm{U} / \mathrm{g} \mathrm{dw}]^{\mathrm{a}}$ & $5.10 \pm 0.22 \mathrm{a}$ & $0.82 \pm 0.5 \mathrm{~b}$ & $0.22 \pm 0.20 \mathrm{~b}$ & $0.69 \pm 0.26 b$ & $8.70 \pm 2.28 \mathrm{c}$ & $0.71 \pm 0.64 b$ \\
\hline Phosphatase $[\mu \mathrm{U} / \mathrm{g} \mathrm{dw}]^{\mathrm{b}}$ & $9.81 \pm 1.68 \mathrm{a}$ & $25.30 \pm 2.63 b$ & $43.49 \pm 2.22 c$ & $14.95 \pm 2.45 \mathrm{a}$ & $18.62 \pm 1.26 b$ & $21.93 \pm 4.12 b$ \\
\hline Arylsulphatase $[\mu \mathrm{U} / \mathrm{g} \mathrm{dw}]^{b}$ & $0.87 \pm 0.28 \mathrm{a}$ & $1.15 \pm 0.16 \mathrm{a}$ & $2.70 \pm 0.18 b$ & $0.39 \pm 0.09 c$ & $0.90 \pm 0.13 \mathrm{a}$ & $0.66 \pm 0.24 \mathrm{ad}$ \\
\hline Protease $[\mu \mathrm{U} / \mathrm{g} \mathrm{dw}]^{\mathrm{b}}$ & $6.21 \pm 0.71 \mathrm{a}$ & $9.63 \pm 1.04 b$ & $13.34 \pm 2.14 \mathrm{c}$ & $8.47 \pm 1.71 \mathrm{ab}$ & $13.99 \pm 0.64 c$ & $24.06 \pm 2.18 \mathrm{~d}$ \\
\hline Glucosidase $[\mu \mathrm{U} / \mathrm{g} \mathrm{dw}]^{\mathrm{b}}$ & $2.41 \pm 0.47 \mathrm{a}$ & $3.02 \pm 0.1 \mathrm{~b}$ & $5.03 \pm 0.24 \mathrm{c}$ & $1.16 \pm 0.19 \mathrm{~d}$ & $1.45 \pm 0.06 \mathrm{~d}$ & $0.67 \pm 0.08 \mathrm{e}$ \\
\hline $\mathrm{PLFA}_{\text {tot }}[\mathrm{mg} / \mathrm{kg} \mathrm{dw}]^{\mathrm{b}}$ & $10.55 \pm 3.65 \mathrm{a}$ & $14.56 \pm 3.76 \mathrm{a}$ & $11.45 \pm 1.45 \mathrm{a}$ & $16.13 \pm 3.17 \mathrm{a}$ & $19.69 \pm 5.01 \mathrm{a}$ & $22.64 \pm 7.34 \mathrm{ab}$ \\
\hline
\end{tabular}

Stress indicator cy/pre PLFA (Figure 8) was increased in comparison to expected values (i.e., 0.4 typical for undisturbed soils [52]) in MIL and OIL variants. Initial values for different soils were significantly different, with the lowest value for AGR and the highest value for OIL. Further monitoring during the experiment showed further development in tested soils. In AGR, the values did not change significantly. In MIL soil, the values were continuously decreasing to the level comparable with AGR. On the other hand, in OIL, the values were continuously increasing during two seasons, indicating a more intense stress response. Revealing the cause of the indicator changes will require significant further research. Nevertheless, we can hypothesize for the positive effect of miscanthus in MIL soil (note that the biomass in OIL was significantly reduced).

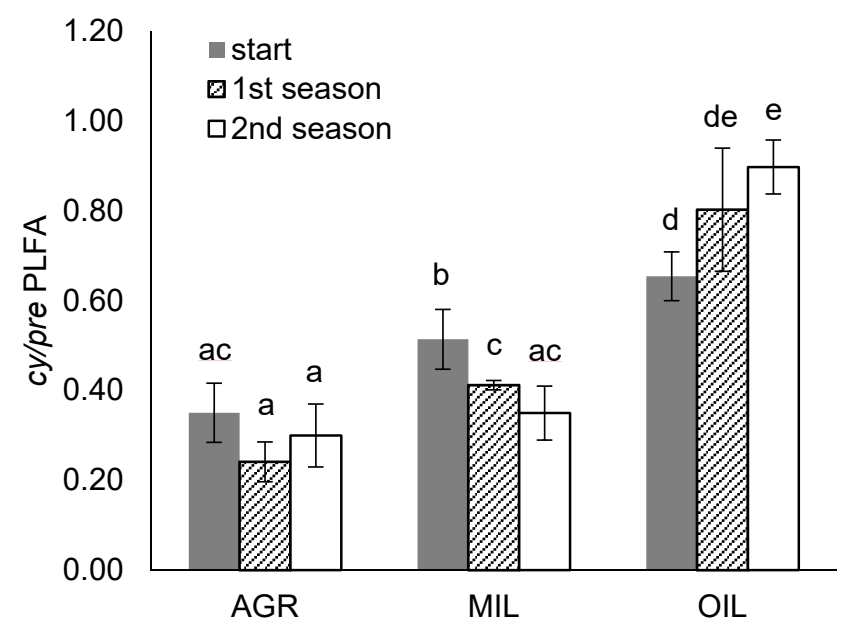

Figure 8. Cy/pre PLFA stress indicators at the beginning and end of the vegetation periods (mean $\pm \mathrm{SD}, \mathrm{n}=4$ ), the same letters above bars mark comparable groups according to Wilcoxon rank-sum test $(p<0.05)$

\section{Discussion}

\subsection{Plant Stress Indicators}

Although molecular methods are irreplaceable in discovering new traits, functions and other parameters [53], much cheaper and less time-consuming methods can be often 
used with satisfactory results for environmental studies like ours. In our case, even simple measuring of biomass parameters revealed differences in tested soils with the highest stress effect of OIL soil and mild effect of MIL soil, which led to decreased biomass production and changes in stem/leaf biomass ratio.

Nevertheless, even if differences are not apparent at first sight, a plant can suffer from stress, which can be detected using more advanced methods [25,30,42,54]. Measuring chlorophyll a fluorescence is one of the methods frequently used in plant studies because it is straightforward, inexpensive and fast. It also represents a sensitive tool for detecting changes in the photosynthesis process caused by different abiotic stress factors [54].

Generally, the values of indexes that were calculated in this study were similar to those measured for plants growing in non-contaminated compost with the same method [44]. That is consistent with previously published results showing that metal contamination does not affect $M x g$ photosynthetic efficiency. In the study of Pogrzeba et al. [55] miscanthus was grown on $\mathrm{Pb}, \mathrm{Cd}, \mathrm{Zn}$ contaminated soil with higher metals concentration than in our case with quantum yield value $(\mathrm{Fv} / \mathrm{Fm})$ close to 0.8 , which is considered as a reference value for non-stress plants measured without using pre-illumination [56]. The same result was obtained by Andrejić et al. [7] for miscanthus grown in mine tailing ponds with a high concentration of $\mathrm{Zn}, \mathrm{Cu}$ and $\mathrm{Pb}$. Wanat et al. [6] determined even slightly higher median values of Fv/Fm for miscanthus grown in post-mining mud waste soils highly contaminated by $\mathrm{As}, \mathrm{Pb}$ and $\mathrm{Sb}$ compared to uncontaminated compost.

On the other hand decrease of Fv/Fm was observed by Andrejić et al. [57] with the same rhizomes as in the previously mentioned field study [7] grown in pots with soil artificially contaminated with $\mathrm{Zn}, 250-1000 \mathrm{mg} / \mathrm{kg}$. So, form and availability of contaminant or synergy with other real contaminated soil factors can play an important role. The stress response in those two experiments of Andrejić et al. could also be affected by a different way of cultivation. Different metal-induced stress response of $M x g$ grown in pot and field was reported by Al Souki [58] the same as different metal sequestration during phytoremediation [59]. Because all results in this study were measured for pot cultivated plants, we may predict that in field conditions the values could be even higher.

In mutual comparison, our fluorescence results supported the conclusion based on biomass results that AGR and MIL soils were more suitable for Mxg growth than OIL soil. In Andrejić et al. [7], changes in leaf pigments content and photosynthetic activity were determined for miscanthus grown in metals contaminated soil of tailing ponds while $\mathrm{Fv} / \mathrm{Fm}$ was comparable with control soil. That suggests that Fv/Fm is not indicator sensitive enough for all types of abiotic stress, which is also claimed by some other authors, for example, Oukarroum et al. [60]. Therefore, we also used other less known indexes to characterize stress levels in plants grown under different soil conditions. Lower values for absorption flux, trapped energy flux and electron transport flux were found, implying decreased PSII activity. Still, mainly in the OIL variant, variability was very high. That is because of the continuous decrease of these plants' physiological states during the measuring period.

From all of these reasons, it was necessary to take a more complex view, investigating more indexes available, together with the investigation of chlorophyll $a$ fluorescence transient (J-I-P test) and microscopy of leaf sections.

Microscopy of leaves can bring us valuable information about changes in anatomy [61]. These changes are usually long-term, like the synthesis of sclerenchyma cells, which have already proved to be a susceptible factor in plants incubated under poor nutrition [44]. Size of sclerenchyma areas varied among left and right border of the leaf (Figure 5, area 1a,b and $2 a, b)$ in both AGR and MIL, but displayed a slight increase in plants grown in agricultural soil, whereas military soil-grown plants possess larger sclerenchymatous areas above and mainly under central veins. According to our knowledge, there is no example in the literature about the different structures of the right and left sides of miscanthus leaves, and this paradox will be further studied. 
AGR leaves had more sclerenchymatous cells on the leaf's edge, and the leaf was also thicker. MIL leaves possess thicker layers of sclerenchyma around the main vascular bundle of the leaf. Since MIL leaves were much thinner than AGR leaves, we hypothesized that in a poor nutrition environment, the MIL plant tried to enhance thin leaf stability at the centre of the leaf where the biggest vascular bundle occurs.

\subsection{Microbial Stress Indicators}

Various approaches for studying stress affecting soil microorganisms are available. To characterize the initial state of microbial communities in this study, it was decided to use the combination of selected enzymatic activities and PLFA profiling as used in previous studies $[11,36,45]$. Based on this data, it could be gathered that the OIL variant was the most beneficial one for microorganisms because it exhibited the highest amount of living microbial biomass $\left(\right.$ PLFA $_{\text {tot }}$ ), soil respiration and dehydrogenase activity, referring to overall soil microbial activity. Most likely, microorganisms capable of utilizing petroleum contamination as a source of carbon and energy were present since they are generally ubiquitous in soils [62].

For stress effect determination during the experiment we focused explicitly on $c y /$ pre PLFA stress indicator, which has proven to be suitable for microbial development monitoring in previous environmental studies, for example, on phytoremediation [11], the effect of tourist traffic in caves [45] and effect of oxidation agents during bioremediation [36]. The increase of cyclopropyl fatty acids in microbial membranes in stress conditions is explained as protective mechanisms occurring during the physiological change from exponential growth to stationary phase (cyclopropylated fatty acids are less rapidly biodegraded), and they are considered indicators of growth inhibition $[47,63]$. This is most likely caused by insufficient nutrients or their suboptimal ratio, but it can have other reasons such as pollution or soil compaction $[45,47]$. Calculation of this indicator is conditioned by the presence of G-bacteria, yet in disturbed and contaminated soils, the abundance of G-bacteria is usually high [47]. That was also our case; the G-PLFA dominated in all samples.

Initial $c y /$ pre PLFA results in our soils were contrary to total microbial biomass and activity, i.e. the highest $c y /$ pre values were found in OIL soil. The lowest $c y / p r e$ stress indicator was determined in AGR soil, the median value was in MIL. These initial values correlated with the stress of plants. Nevertheless, the disadvantage of this indicator is that it cannot identify the specific cause of stress. Dominantly, the $c y /$ pre values are connected with nutrition deficiencies (in our case, the ratios of C:N and C:P are very likely). However, the contamination concentration and synergy of contaminants or high $\mathrm{pH}$ and Ca content could also increase stress. During two vegetation seasons in AGR and MIL cy/pre PLFA continuously decreased below significant stress value 0.4 (MIL) or stayed at a non-stressed level (AGR). The same development was reported in our previous pot study with miscanthus in soil with elevated concentrations of $\mathrm{As}, \mathrm{Zn}, \mathrm{Cu}, \mathrm{Sr}$ and $\mathrm{Zr}$ [11]. On the contrary, in the OIL variant with soil from petroleum sludge, it increased continuously.

That can lead to the hypothesis that well-developed plat roots in AGR and MIL soil could help with microbial community stabilization and stress reduction, while a weak small plant with stunted roots in OIL soil did not support soil microorganisms. That is in agreement with some previous conclusions. Al Souki et al. [58] reported increased soil biological activities (basal soil respiration and selected enzymatic activities) and increased microbial biomass carbon in a field planted with miscanthus compared to an unplanted area. The short-term effect of miscanthus cultivation on soil microorganisms compared to plot with conventional wheat cropping system with annual crops in soil contaminated by long-term wastewater irrigation was studied by Bourgeois et al. [64]. According to their results, miscanthus stimulated several genera of bacteria that are involved in plant-bacteria symbioses such as Rhizobiales and Nitrospira. 


\subsection{Application for Phytomanagement}

Miscanthus $x$ giganteus is a fast-growing C4 plant with good nutrient management and high yields of suitable biomass [3]. Therefore, the recent research has also been oriented to its cultivation on contaminated or marginal land, resulting in sustainable joint phytomanagement/phytoremediation with biomass production. Miscanthus was confirmed as a plant suitable for such applications in metal contaminated soils as reported previously $[5,55,65,66]$. Much less experimental work was done with organic contaminants, particularly petroleum, one of the most abundant environmental pollution sources.

Many factors could contribute to miscanthus growth starting from macro and micronutrients in the soil, their availability, climate and weather, water availability, quantity and quality of contamination, including synergic effects, other stresses, etc. It is very complicated to uncover all factors when aiming at real contaminated soils. Therefore, it is common in bioremediation practice that preliminary case experiments similar to ours are carried out to obtain data for the field experiment [36,46]. Information about plant and microbial stress response is very useful for planning complex phytomanagement of contaminated sites. The tolerance to specific contamination is one of the essential requirements for choosing a suitable plant, and stimulation of soil microorganisms is crucial for rhizodegradation.

In AGR soil with agricultural contamination by $\mathrm{Cd}$ and MIL soil with low-level $\mathrm{Pb}$ contamination, $\mathrm{Zn}$ and $\mathrm{Cd} M x g$ produced a satisfactory amount of biomass. The good physiological state of plants, was also confirmed by chlorophyll fluorescence measuring and microscopy. Additionally, reduction of microbial stress was recorded in these two variants. The opposite result was obtained for miscanthus grown in real soil from petroleum sludge lagoon with cross-contamination. Plants could survive, but biomass production was deficient, and no microbial stress reduction was determined.

Our previous study also determined a significant decrease of calorific value for the biomass grown in petroleum industry contaminated soil [67]. This notion implicates it would be less useful to use the biomass for combustion compared to AGR and MIL soils, which had values comparable with middle-quality brown coal or pine wood.

Based on these results, $M x g$ should not be considered a good remediation agent for the tested OIL soil contaminated by the petroleum industry. However, we could not attribute these negative results to petroleum contamination since we were neither able to cover other possible pollutants nor evaluate likely synergies. More research and metaanalyses of many other case-studies will be needed to identify significant general factors or their combinations affecting the $M x g$ and effective measures to compensate them. Field experiments are also required to verify the results in real-scale conditions and to receive long-term data that cannot be collected in short-term pot experiment with young plants.

\section{Conclusions}

Miscanthus $x$ giganteus was tested as a plant suitable for growing in different contaminated soils-agricultural soil contaminated with Cd, post-military soil slightly contaminated with $\mathrm{Zn}, \mathrm{Pb}$ and $\mathrm{Cd}$ and soil contaminated petroleum industry with mixed metals and hydrocarbons contamination. Results for only metals contaminated soils (agricultural and post-military) were mainly positive. They confirmed miscanthus as a plant suitable for biomass production in these soils, and the plant vitality was not significantly affected. Additionally, reduced or no stress of soil microorganisms was determined in these variants during the experiment. On the other hand, soil contaminated by the petroleum industry does not seem to be tolerable because biomass yield was dramatically reduced and the plant physiological indicators were significantly negatively affected. Moreover, conversely to other soils, microbial community stress increased year-on-year.

It was found that $\mathrm{Fv} / \mathrm{Fm}$ fluorescence index, the most used one elsewhere, was not sensitive enough to reveal significant changes in plant fitness, which were confirmed by other methods and indexes (OKJIP curve, $\mathrm{TR}_{0} / \mathrm{CS}_{0}, \mathrm{ET}_{0} / \mathrm{CSm}, \mathrm{ABS} / \mathrm{CSm}$ ). Additionally, leaf anatomy changes (leaf thickness, sclerenchyma cells area) were also observed between variants that were identified as comparable by chlorophyll a fluorescence analysis. So, it 
was recommended to use a combination of those methods to get more complex information about the plants stress response.

Author Contributions: Conceptualization, D.N., J.T., H.A.M. and V.P.; methodology, D.N., J.T., H.A.M., V.P. and P.K.; validation, D.N., J.T. and H.A.M.; formal analysis, A.E. and D.N.; investigation, D.N., A.E., A.M., M.S.; writing—original draft preparation, D.N., H.A.M. and J.T.; writing-review and editing, J.T.; visualization, D.N. and A.E.; supervision, J.T.; project administration, V.P.; funding acquisition, V.P. All authors have read and agreed to the published version of the manuscript.

Funding: This research was funded by NATO Science for Peace and Security Programme MYP G4687 and the involvement of students was covered by internal Student grant competition at UJEP grant number UJEP-SGS-2017-44-003-3 and UJEP-SGS-2020-44-001-2. The equipment for analyses was provided within the Research infrastructure NanoEnviCZ supported by the Ministry of Education, Youth and Sports of the Czech Republic grant number LM2015073.

Institutional Review Board Statement: Not applicable.

Informed Consent Statement: Not applicable.

Acknowledgments: We would like to thank Sergej Ust'ak for providing us measurement of soil agrochemical properties and Ethan Nicolas Duong for language proofreading.

Conflicts of Interest: The authors declare no conflict of interest.

\section{References}

1. Ashraf, M.A.; Maah, M.J.; Yusoff, I. Soil Contamination, Risk Assessment and Remediation. In Environmental Risk Assessment of Soil Contamination; Hernandez Soriano, M.C., Ed.; IntechOpen: London, UK, 2014; pp. 1-56. ISBN 978-953-51-1235-8.

2. Gerwin, W.; Repmann, F.; Galatsidas, S.; Vlachaki, D.; Gounaris, N.; Baumgarten, W.; Volkmann, C.; Keramitzis, D.; Kiourtsis, F.; Freese, D. Assessment and quantification of marginal lands for biomass production in Europe using soil-quality indicators. Soil 2018, 4, 267-290. [CrossRef]

3. Pidlisnyuk, V.; Stefanovska, T.; Lewis, E.E.; Erickson, L.E.; Davis, L.C. Miscanthus as a productive biofuel crop for phytoremediation. CRC Crit. Rev. Plant Sci. 2014, 33, 1-19. [CrossRef]

4. Pogrzeba, M.; Rusinowski, S.; Krzyżak, J. Macroelements and heavy metals content in energy crops cultivated on contaminated soil under different fertilization-case studies on autumn harvest. Environ. Sci. Pollut. Res. 2018, 25, 12096-12106. [CrossRef] [PubMed]

5. Pidlisnyuk, V.; Erickson, L.; Stefanovska, T.; Popelka, J.; Hettiarachchi, G.; Davis, L.; Trögl, J. Potential phytomanagement of military polluted sites and biomass production using biofuel crop miscanthus x giganteus. Environ. Pollut. 2019, 249, 330-337. [CrossRef]

6. Wanat, N.; Austruy, A.; Joussein, E.; Soubrand, M.; Hitmi, A.; Gauthier-Moussard, C.; Lenain, J.-F.; Vernay, P.; Munch, J.C.; Pichon, M. Potentials of Miscanthus x giganteus grown on highly contaminated Technosols. J. Geochem. Explor. 2013, 126-127, 78-84. [CrossRef]

7. Andrejić, G.; Šinžar-Sekulić, J.; Prica, M.; Dželetović, Ž.; Rakić, T. Phytoremediation potential and physiological response of Miscanthus $\times$ giganteus cultivated on fertilized and non-fertilized flotation tailings. Environ. Sci. Pollut. Res. 2019, 26, 34658-34669. [CrossRef]

8. Cadoux, S.; Riche, A.B.; Yates, N.E.; Machet, J.-M. Nutrient requirements of Miscanthus x giganteus: Conclusions from a review of published studies. Biomass Bioenergy 2012, 38, 14-22. [CrossRef]

9. Lewandowski, I.; Clifton-Brown, J.C.; Scurlock, J.M.O.; Huisman, W. Miscanthus: European experience with a novel energy crop. Biomass Bioenergy 2000, 19, 209-227. [CrossRef]

10. Christensen, B.T.; Lærke, P.E.; Jørgensen, U.; Kandel, T.P.; Thomsen, I.K. Storage of Miscanthus-derived carbon in rhizomes, roots, and soil. Can. J. Soil Sci. 2016, 96, 354-360. [CrossRef]

11. Nebeská, D.; Trögl, J.; Pidlisnyuk, V.; Popelka, J.; Veronesi Dáňová, P.; Ust'ak, S.; Honzík, R. Effect of Growing Miscanthus x giganteus on soil microbial communities in post-military soil. Sustainability 2018, 10, 4021. [CrossRef]

12. Brosse, N.; Dufour, A.; Meng, X.; Sun, Q.; Ragauskas, A.J. Miscanthus: A fast-growing crop for biofuels and chemicals production. Biofuels Bioprod. Biorefining 2012, 6, 580-598. [CrossRef]

13. Van Der Weijde, T.; Alvim Kamei, C.L.; Torres, A.F.; Evermerris, W.; Edolstra, O.; Visser, R.G.F.; Trindade, L.M. The potential of C4 grasses for cellulosic biofuel production. Front. Plant Sci. 2013, 4, 107. [CrossRef]

14. van Hulle, S.; van Waes, C.; De Vliegher, A.; Baert, J.; Muylle, H. Comparison of dry matter yield of lignocellulosic perennial energy crops in a longterm Belgian field experiment. In Proceedings of the Grassland Science in Europe: Grassland-A European Resource, Lublin, Poland, 3-7 June 2012; pp. 499-501.

15. Daraban, A.E.; Jurcoane, S..; Voicea, I.; Voicu, G. Miscanthus giganteus biomass for sustainable energy in small scale heating systems. Agric. Agric. Sci. Procedia 2015, 6, 538-544. [CrossRef] 
16. Nsanganwimana, F.; Pourrut, B.; Mench, M.; Douay, F. Suitability of Miscanthus species for managing inorganic and organic contaminated land and restoring ecosystem services. A review. J. Environ. Manag. 2014, 143, 123-134. [CrossRef]

17. Técher, D.; Laval-Gilly, P.; Henry, S.; Bennasroune, A.; Formanek, P.; Martinez-Chois, C.; D’Innocenzo, M.; Muanda, F.; Dicko, A.; Rejšek, K.; et al. Contribution of Miscanthus x giganteus root exudates to the biostimulation of PAH degradation: An in vitro study. Sci. Total. Environ. 2011, 409, 4489-4495. [CrossRef] [PubMed]

18. Techer, D.; D’Innocenzo, M.; Laval-Gilly, P.; Henry, S.; Bennasroune, A.; Martinez-Chois, C.; Falla, J. Assessment of Miscanthus $\times$ giganteus secondary root metabolites for the biostimulation of PAH-utilizing soil bacteria. Appl. Soil Ecol. 2012, 62, 142-146. [CrossRef]

19. Techer, D.; Martinez-Chois, C.; Laval-Gilly, P.; Henry, S.; Bennasroune, A.; D'Innocenzo, M.; Falla, J. Assessment of Miscanthus $\times$ giganteus for rhizoremediation of long term PAH contaminated soils. Appl. Soil Ecol. 2012, 62, 42-49. [CrossRef]

20. Nurzhanova, A.; Pidlisnyuk, V.; Kalugin, S.; Stefanovska, T.; Drimal, M. Miscanthus x giganteus as a new highly efficient phytoremediation agent for improving soils contaminated by pesticides residues and supplemented contaminants. Commun. Agric. Appl. Boil. Sci. 2015, 80, 361-366.

21. Lim, M.W.; Von Lau, E.; Poh, P.E. A comprehensive guide of remediation technologies for oil contaminated soil-Present works and future directions. Mar. Pollut. Bull. 2016, 109, 14-45. [CrossRef]

22. Megharaj, M.; Ramakrishnan, B.; Venkateswarlu, K.; Sethunathan, N.; Naidu, R. Bioremediation approaches for organic pollutants: A critical perspective. Environ. Int. 2011, 37, 1362-1375. [CrossRef]

23. Da Costa, R.M.F.; Simister, R.; Roberts, L.A.; Timms-Taravella, E.; Cambler, A.B.; Corke, F.M.K.; Han, J.; Ward, R.J.; Buckeridge, M.S.; Gomez, L.D.; et al. Nutrient and drought stress: Implications for phenology and biomass quality in miscanthus. Ann. Bot. 2019, 124, 553-566. [CrossRef]

24. Lichtenthaler, H.K. Vegetation stress: An introduction to the stress concept in plants. J. Plant Physiol. 1996, 148, 4-14. [CrossRef]

25. He, J.X.; Wang, J.; Liang, H.G. Effects of water stress on photochemical function and protein metabolism of photosystem II in wheat leaves. Physiol. Plant. 1995, 93, 771-777. [CrossRef]

26. Baker, N.R. A possible role for photosystem II in environmental perturbations of photosynthesis. Physiol. Plant. 1991, 81, 563-570. [CrossRef]

27. Strasser, R.J.; Srivastava, A.G. Polyphasic chlorophyll a fluorescence transient in plants and cyanobacteriatle. Photochem. Photobiol. 1995, 61, 32-42. [CrossRef]

28. Strasser, R.J.; Greppin, H. Primary reactions of photochemistry in higher plants. In Photosynthesis III: Structure and Molecular Organisation of the Photosynthetic Apparatus; Akoyunoglou, G., Ed.; Balaban International Science Services: Philiadelphia, PA, USA, 1981; pp. 717-726.

29. Strasser, R.J.; Stirbet, A.D. Heterogeneity of photosystem II probed by the numerically simulated chlorophyll a fluorescence rise (O-J-I-P). Math. Comput. Simul. 1998, 48, 3-9. [CrossRef]

30. Strasser, R.J.; Tsimilli-Michael, M.; Srivastava, A. Analysis of the chlorophyll a fluorescence transient. In Advances in Photosynthesis and Respiration; Papageorgiou, G.C., Govindjee, Eds.; Springer: Dordrecht, The Netherlands, 2004; Volume 19, pp. 321-362.

31. Butler, W.L.; Strasser, R.J. Tripartite model for the photochemical apparatus of green plant photosynthesis. Proc. Natl. Acad. Sci. USA 1977, 74, 3382-3385. [CrossRef]

32. Truu, J.; Truu, M.; Espenberg, M.; Nõlvak, H.; Juhanson, J. Phytoremediation and plant-assisted bioremediation in soil and treatment wetlands: A review. Open Biotechnol. J. 2015, 9, 85-92. [CrossRef]

33. Ministry of the Environment of the Czech Republic. Vyhláška č. 153/2016 Sb. o Stanovení Podrobností ochrany Kvality Zemědělské Půdy a o Změně Vyhlášky č. 13/1994 Sb., kterou se Upravují Některé Podrobnosti ochrany Zemědělského Půdního Fondu. 2016. Available online: https:/ /www.mzp.cz/www/platnalegislativa.nsf/334D37465BA483E2C125800A0029EF9C/\%2 4file/V153_2016.pdf (accessed on 19 February 2021)[In Czech].

34. Machackova, J.; Wittlingerova, Z.; Vlk, K.; Zima, J.; Linka, A. Comparison of Two Methods for Assessment of In Situ Jet-fuel Remediation Efficiency. Water Air Soil Pollut. 2007, 187, 181-194. [CrossRef]

35. Macháčková, J.; Wittlingerova, Z.; Vlk, K.; Zima, J. Major factors affecting in situ biodegradation rates of jet-fuel during large-scale biosparging project in sedimentary bedrock. J. Environ. Sci. Heal. Part A Toxic Hazard. Subst. Environ. Eng. 2012, 47, 1152-1165. [CrossRef]

36. Kakosová, E.; Hrabák, P.; Černík, M.; Novotný, V.; Czinnerová, M.; Trögl, J.; Popelka, J.; Kuráň, P.; Zoubková, L.; Vrtoch, L'. Effect of various chemical oxidation agents on soil microbial communities. Chem. Eng. J. 2017, 314, 257-265. [CrossRef]

37. Trögl, J.; Esuola, C.O.; Kříženecká, S.; Kuráň, P.; Seidlová, L.; Veronesi-Dáňová, P.; Popelka, J.; Babalola, O.O.; Hrabák, P.; Czinnerová, M.; et al. Biodegradation of high concentrations of aliphatic hydrocarbons in soil from a petroleum refinery: Implications for applicability of new actinobacterial strains. Appl. Sci. 2018, 8, 1855. [CrossRef]

38. Zbíral, J.; Malý, S.; Váňa, M.; Čuhel, J.; Fojtlová, E.; Čižmár, D.; Žalmanová, A.; Srnková, J.; Obdržálková, E. Jednotné Pracovní Postupy: Analýza puid III; Central Institute for Supervising and Testing in Agriculture: Brno, Czech Republic, 2011; [In Czech].

39. Zbíral, J.; Čižmárová, E.; Obdržálková, E.; Rychlý, M.; Vilamová, V.; Srnková, J.; Žalmanová, A. Jednotné pracovní postupy: Analýza půd I; Central Institute for Supervising and Testing in Agriculture: Brno, Czech Republic, 2016; [In Czech].

40. Czech Normalization Institute. ČSN EN 14039 (838025): Characterization of Waste-Determination of Hydrocarbon Content in the Range of C10 to C40 by Gas Chromatography. 2005. Available online: https://standards.iteh.ai/catalog/standards/sist/d3 d6675b-b3c0-4b3e-9b28-9359c4173d57/ sist-en-14039-2005 (accessed on 19 February 2021). 
41. Kuráň, P.; Nováková, J.; Janoš, P. Determination of hydrocarbon index of C10-C40 in composts and sludges by GC-FID with traditional split/splitless injector. Chem. List. 2011, 105, 133-137.

42. Krause, G.H.; Weis, E. Chlorophyll fluorescence as a tool in plant physiology-II. Interpretation of fluorescence signals. Photosynth Res. 1984, 5, 139-157. [CrossRef]

43. Rusinowski, S.; Krzyżak, J.; Sitko, K.; Kalaji, H.; Jensen, E.; Pogrzeba, M. Cultivation of C4 perennial energy grasses on heavy metal contaminated arable land: Impact on soil, biomass, and photosynthetic traits. Environ. Pollut. 2019, 250, 300-311. [CrossRef] [PubMed]

44. Malinská, H.; Pidlisnyuk, V.; Nebeská, D.; Erol, A.; Medžová, A.; Trögl, J. Physiological response of Miscanthus x giganteus to plant growth regulators in nutritionally poor soil. Plants 2020, 9, 194. [CrossRef]

45. Kukla, J.; Holec, M.; Trögl, J.; Holcová, D.; Hofmanová, D.; Kuran, P.; Popelka, J.; Pacina, J.; Kř́ženecká, S.; Ust’ak, S.; et al. Tourist traffic significantly affects microbial communities of sandstone cave sediments in the protected landscape area "Labské Pískovce" (Czech Republic): Implications for regulatory measures. Sustainability 2018, 10, 396. [CrossRef]

46. Kuráň, P.; Trögl, J.; Nováková, J.; Pilařová, V.; Dáňová, P.; Pavlorková, J.; Kozler, J.; Novák, F.; Popelka, J. Biodegradation of spilled diesel fuel in agricultural soil: Effect of humates, zeolite, and bioaugmentation. Sci. World J. 2014, 2014, 1-8. [CrossRef]

47. Kaur, A.; Chaudhary, A.; Kaur, A.; Choudhary, R.; Kaushik, R. Phospholipid fatty acid-A bioindicator of environment monitoring and assessment in soil ecosystem. Curr. Sci. 2005, 89. [CrossRef]

48. Baldrian, P.; Trögl, J.; Frouz, J.; Šnajdr, J.; Valášková, V.; Merhautová, V.; Cajthaml, T.; Herinková, J. Enzyme activities and microbial biomass in topsoil layer during spontaneous succession in spoil heaps after brown coal mining. Soil Biol. Biochem. 2008, 40, 2107-2115. [CrossRef]

49. R Core Team. R: A Language and Environment for Statistical Computing; R Foundation for Statistical Computing: Vienna, Austria, 2014.

50. Ministry of Agriculture of the Czech Republic. Vyhláška č. 335/2017 Sb. Vyhláška, Kterou se Mění Vyhláška č. 275/1998 Sb., o Agrochemickém Zkoušení Zemědělských půd a Zjišt'ování Půdních Vlastností Lesních Pozemků. 2017. Available online: http: / / eagri.cz/public/web/ws_content?contentKind=regulation\&section=1\&id=89157\&name=335/2017 (accessed on 19 February 2021)[In Czech].

51. Roberts, T.L. Cadmium and phosphorous fertilizers: The issues and the science. Procedia Eng. 2014, 83, 52-59. [CrossRef]

52. Moore-Kucera, J.; Dick, R.P. PLFA Profiling of microbial community structure and seasonal shifts in soils of a douglas-fir chronosequence. Microb. Ecol. 2008, 55, 500-511. [CrossRef]

53. Shulaev, V.; Cortes, D.; Miller, G.; Mittler, R. Metabolomics for plant stress response. Physiol. Plant. 2008, 132, 199-208. [CrossRef] [PubMed]

54. Kalaji, H.M.; Jajoo, A.; Oukarroum, A.; Brestic, M.; Zivcak, M.; Samborska, I.A.; Cetner, M.D.; Łukasik, I.; Goltsev, V.; Ladle, R.J. Chlorophyll a fluorescence as a tool to monitor physiological status of plants under abiotic stress conditions. Acta Physiol. Plant. 2016, 38, 102. [CrossRef]

55. Pogrzeba, M.; Rusinowski, S.; Sitko, K.; Krzyżak, J.; Skalska, A.; Małkowski, E.; Ciszek, D.; Werle, S.; McCalmont, J.P.; Mos, M.; et al. Relationships between soil parameters and physiological status of Miscanthus $\mathrm{x}$ giganteus cultivated on soil contaminated with trace elements under NPK fertilisation vs. microbial inoculation. Environ. Pollut. 2017, 225, 163-174. [CrossRef] [PubMed]

56. Björkman, O.; Demmig, B. Photon yield of O2 evolution and chlorophyll fluorescence characteristics at $77 \mathrm{~K}$ among vascular plants of diverse origins. Planta 1987, 170, 489-504. [CrossRef]

57. Andrejic, G.; Gajic, G.; Prica, M.; Dzeletovic, Z.; Rakic, T. Zinc accumulation, photosynthetic gas exchange, and chlorophyll a fluorescence in Zn-stressed Miscanthus x giganteus plants. Photosynthetica 2018, 56, 1249-1258. [CrossRef]

58. Al Souki, K.S. Soil-Plant Interactions in the Context of Phytomanagement of Soil Contaminated by Metals: Application to Miscanthus x Giganteus. 2017. Available online: https:/ / ori-nuxeo.univ-lille1.fr/nuxeo/site/esupversions/3d97d962-4ef8-48b3 -8a97-ba14e363e0ee (accessed on 19 February 2021).

59. Pelfrêne, A.; Kleckerova, A.; Pourrut, B.; Nsanganwimana, F.; Douay, F.; Waterlot, C. Effect of Miscanthus cultivation on metal fractionation and human bioaccessibility in metal-contaminated soils: Comparison between greenhouse and field experiments. Environ. Sci. Pollut. Res. 2015, 22, 3043-3054. [CrossRef]

60. Oukarroum, A.; El Madidi, S.; Schansker, G.; Strasser, R.J. Probing the responses of barley cultivars (Hordeum vulgare L.) by chlorophyll a fluorescence OLKJIP under drought stress and re-watering. Environ. Exp. Bot. 2007, 60, 438-446. [CrossRef]

61. Bilska-Kos, A.; Panek, P.; Szulc-Głaz, A.; Ochodzki, P.; Cisło, A.; Żebrowski, J. Chilling-induced physiological, anatomical and biochemical responses in the leaves of Miscanthus $\times$ giganteus and maize (Zea mays L.). J. Plant Physiol. 2018, 228, 178-188. [CrossRef]

62. Tyagi, M.; Da Fonseca, M.M.R.; De Carvalho, C.C.C.R. Bioaugmentation and biostimulation strategies to improve the effectiveness of bioremediation processes. Biogeochem. 2010, 22, 231-241. [CrossRef] [PubMed]

63. Frostegård, Å.; Tunlid, A.; Bååth, E. Use and misuse of PLFA measurements in soils. Soil Biol. Biochem. 2011, 43, 1621-1625. [CrossRef]

64. Bourgeois, E.; Dequiedt, S.; Lelièvre, M.; Van Oort, F.; Lamy, I.; Ranjard, L.; Maron, P.A. Miscanthus bioenergy crop stimulates nutrient-cycler bacteria and fungi in wastewater-contaminated agricultural soil. Environ. Chem. Lett. 2015, 13, 503-511. [CrossRef]

65. Al Souki, K.S.; Louvel, B.; Douay, F.; Pourrut, B. Assessment of Miscanthus x giganteus capacity to restore the functionality of metal-contaminated soils: Ex situ experiment. Appl. Soil Ecol. 2017, 115, 44-52. [CrossRef] 
66. Kocoń, A.; Jurga, B. The evaluation of growth and phytoextraction potential of Miscanthus $x$ giganteus and Sida hermaphrodita on soil contaminated simultaneously with Cd, Cu, Ni, Pb, and Zn. Environ. Sci. Pollut. Res. 2017, 24, 4990-5000. [CrossRef]

67. Nebeská, D.; Trögl, J.; Žofková, D.; Voslařová, A.; Štojdl, J.; Pidlisnyuk, V. Calorific values of Miscanthus x giganteus biomass cultivated under suboptimal conditions in marginal soils. Stud. Oecologica 2019, 13, 61-67. [CrossRef] 